\title{
МЕХАНИЗМ ИСПОЛЬЗОВАНИЯ ПРОЕКТНОГО ФИНАНСИРОВАНИЯ КАК СПОСОБА ВЗАИМОДЕЙСТВИЯ БАНКА И ПРЕДПРИЯТИЯ В ОСУЩЕСТВЛЕНИИ ИНВЕСТИЦИЙ
}

\author{
Тавбулатова 3.К., \\ Хаханаев У. С-Э. \\ ФГБОУ ВО «Чеченский государственный университет», \\ г. Грозный, Россия
}

Статья посвящена исследованию механизма использования проектного финансирования как способа взаимодействия банка и предприятия или отдельных отраслей экономики. В статье рассмотрены исторические этапы возникновения и использования проектного финансирования как способа кредитования предприятий в зарубежных странах и в России. Отдельно изучен опыт реализации механизма проектного финансирования Фабрикой проектной финансирования ВЭБ.РФ. Сделан статистический анализ структуры кредитования банком отдельных направлений хозяйствования $c$ использованием механизма проектного финансирования. Сделаны выводы о преимуществах и целесообразности использования банками проектного способа кредитования отдельных проектов.

Ключевые слова: история проектного финансирования, кредит, механизмы, инвестиции, проекты, «ВЭБ. РФ».

Проектное финансирование в наше новое время стало ассоциироваться с такими словами как «Гарантия», «Качество», «Результат». На самом деле к проектному финансированию финансовые институты приходят или пришли уже на протяжении столетия. Некоторые специалисты полагают, что начало проектному финансированию было положено вначале 1930-х гг., когда впервые финансирование подобного рода было использовано при разработке нефтяных месторождений в Соединённых Штатах Америки. Для финансирования была задействована схема, при которой кредит, выдаваемый под обеспечение в виде разведанных запасов нефти, погашался за счет доходов, получаемых от ее продаж.

Таким образом, в XX веке первая сделка, впоследствии получившая название проектного финансирования, состоялась в 1930-е года в штате Техас (США) и была связана с финансированием нефтедобывающей проектной компании.

Российские исследователи данной проблемы В.Ю. Катасонов и Д.С. Морозов считают, что история проектного финансирования берет свое начало с 1970 гг. и связана она с «нефтяным бумом». По их мнению, схемы проектного финансирования в современном их понимании начали использоваться в Европе в 1970-е гг. в связи с геологоразведкой и началом крупномасштабной 
разработки нефтегазовых залежей в Северном море. В данном случае использовалась довольно примитивная схема финансирования: кредит выдавался компаниям под обеспечение в форме разведанных запасов нефти и погашался за счет доходов от ее продаж. Таким образом, можно сказать, современное проектное финансирование - производная такой известной банковской операции, как погашение кредита произведенной продукции $[1, \mathrm{c}$. 72].

В современное время проектное финансирование используется, т.е. более распространено в промышленно развитых странах, поскольку такая форма считается перспективным направлением активного взаимодействия реального сектора экономики и финансово-банковской сферы.

Классическим примером проектного финансирования в Европе можно назвать крупномасштабный проект «Евротоннель» (тоннель под Ла-Маншем) соединивший Великобританию и Францию железной дорогой. Начало строительства железной дороги было заложено в 1883 году. Данный проект на тот момент оценивался в 1 млн. фунтов стерлингов. Вклад частного финансирования в таком сложном проекте был внушительным: 45 млн. фунтов стерлингов было привлечено через CTG/F-M, 770 млн. фунтов стерлингов через публичное размещение акций, 206 млн. фунтов стерлингов дали частные институциональные инвесторы, также был оформлен синдицированный банковский кредит до 5 млрд. фунтов стерлингов. Оценочная стоимость проекта в 1985 году составила 2,6 млрд. фунтов стерлингов. К концу строительства фактические расходы составили 4,65 млрд. фунтов стерлингов из-за повышения требований к безопасности и экологичности тоннеля. По другим оценкам, всего на реализацию проекта «Евротоннель» было потрачено около 10 млрд. фунтов стерлингов (с учётом инфляции) [2].

На начальных этапах становления проектного финансирования на рынке преобладали американские и канадские банки. Затем к оказанию такого вида услуг подключились банки Великобритании, а за последние 10 лет - крупные банки Франции, Германии, Японии, Китая, Индии и др.

В России проектное финансирование начало развиваться вначале 1990-х гг. В 1990-х гг. Россия участвовала в нескольких международных проектах на принципах проектного финансирования - «Морской старт», «Голубой поток», «Сахалин-2». В те годы в российских банках были подразделения проектного финансирования, которые в основном занимались инвестиционным кредитованием, в качестве заемщика рассматривалось действующее предприятие, которому требовалось финансирование реализуемого инвестиционного проекта. Вся процедура рассмотрения заявки и принятия решения о кредитовании предприятия в этом случае осуществлялась в соответствии с нормативными документами Центробанка РФ. Наибольшего прогресса в развитии инновационного кредитования и проектного финансирования добились Сбербанк России, ВТБ, Росбанк.

В настоящее время проектное финансирование, соответствующее современному определению, принципам и моделям, применяется в 
большинстве крупных коммерческих банках России, а также в госкорпорации «Банк развития и внеэкономической деятельности» и Евразийском банке развития.

Мировая практика проектного финансирования выработала три основных вида проектного финансирования: банковское, корпоративное, с участием государства.

Более детально вопросы банковского проектного финансирования, исследованы в трудах М. А. Федотова, И. А. Никонова, Н. А. Лысова [1].

Ими издано учебное пособие по данному курсу, которое позволяет и практикам и обучающимся разобраться в азах теоретико-категориального понимания дефиниции «проектное финансирование» и дают общетеоретические знания о достаточно новой отрасли знаний в экономике. Авторы считают, что банковское проектное финансирование (когда банк или несколько банков организуют финансирование инвестиционного проекта) различаются по следующим видам:

- без права регресса (оборота) банка, при этом возможность предъявления регрессивных исков к компаниям, принимающим участие в проекте, практически полностью исключается; заемщик не имеет активов для обеспечения возврата заемных средств; выплата процентов и погашение ссуд гарантируется за счет движения денежного потока и активов самого проекта; это вид «чистого» проектного финансирования; это наиболее рисковая схема финансирования и наиболее дорогая для проектной компании;

- c ограниченным регрессом (оборотом) банка, при этом проектная компания либо сама имеет частичное обеспечение, либо его представители третьи лица (например, спонсоры проекта); это наиболее распространённый вид проектного финансирования;

- с полным регрессом (оборотом) банка на заемщика - традиционное кредитование; инициатор проекта отражает проект на своем балансе и несет полную ответственность за возврат заемных средств [1].

При проектном финансировании банками развития основными инструментами служат кредитование, участие в капитале проектной компании (покупка акций, долей), предоставление гарантий, поручительств, приобретение облигаций проектных компаний при их первичном размещении. Доля кредитов в структуре проектного финансирования проекта составляет не более $80 \%$.

Одну из важнейшей роли в инвестировании проектов в Российской Федерации занимает государственная корпорация «ВЭБ. РФ». ВЭБ.РФ действует в целях содействия в обеспечении долгосрочного социальноэкономического развития Российской Федерации и создании условий для устойчивого экономического роста, повышения эффективности инвестиционной деятельности и расширения инвестирования средств в национальную экономику посредством реализации проектов в Российской Федерации и за рубежом, в том числе с участием иностранного капитала, направленных на развитие инфраструктуры, промышленности, инноваций, 
особых экономических зон, защиту окружающей среды, повышение энергоэффективности, поддержку экспорта и расширение доступа российской промышленной продукции (товаров, работ, услуг) на зарубежные рынки, а также иных проектов и (или) сделок в рамках осуществления инвестиционной, внешнеэкономической, консультационной и иной предусмотренной настоящим Федеральным законом деятельности [3].

Рассмотрим механизм использования проектного финансирования ВЭБ.РФ. Для бизнеса ВЭБ.РФ использует Программу «Фабрика проектного финансирования» утвержденную Постановлением Правительства Российской Федерации от 15 февраля 2018 г. № 158.

Отметим, что фабрика - это механизм проектного финансирования инвестиционных проектов в приоритетных секторах российской экономики, предусматривающий предоставление денежных средств заемщикам на основании договоров синдицированного кредита (займа), реализуемых с применением мер государственной поддержки и способствующих увеличению объемов кредитования организаций, реализующих инвестиционные проекты. Здесь важную роль в отборе проектов для финансирования имеет критериальный подход. Фабрика проектного финансирования для отбора проектов использует три основных критерия:

a) проект на территории РФ от 3 млрд. руб;

b) окупаемость проекта до 20 лет;

c) собственные средства инициатора проекта - не менее $20 \%$ от суммы

d) бюджета проекта;

е) проект реализуется на основе проектного финансирования.

Процесс отбора проектов Фабрикой проектного финансирования ВЭБ.РФ проходит в четыре этапа (таблица 1) Алгоритм отбора выглядит следующим образом: на первом этапе определяются источники проектов, на втором этапе сформировывается Реестр потенциальных проектов Фабрики, на третьем этапе уже сформировывается окончательный Реестр проектов Фабрики, на последнем этапе проходит мониторинг проекта на всех этапах его жизненного цикла.

Таблица 1 - Процесс отбора проектов Фабрики проектного финансирования ВЭБ. РФ

\begin{tabular}{|c|c|}
\hline І. БИЗНЕС ИДЕЯ & $\begin{array}{l}\text { Источники проектов: } \\
\text { - } \text { ВЭБ.РФ; } \\
\text { - } \text { инициаторы проекта; } \\
\text { - участники фабрики. }\end{array}$ \\
\hline II. ОТБОР В ФАБРИКУ & $\begin{aligned} & \text { ВЭБ.РФ проверяет соответствие критериям } \\
& \text { Фабрики; } \\
& \checkmark \\
& \text { заемщик дает согласие на включение } \\
& \text { проекта в Фабрику; } \\
& \checkmark \text { ВЭБ.РФ принимает решение о } \\
& \text { потенциальной возможности включения } \\
& \text { проекта в Фабрику; }\end{aligned}$ \\
\hline
\end{tabular}




\begin{tabular}{|c|c|}
\hline & $\begin{array}{l}\checkmark \text { коммерческие банки выражают } \\
\text { заинтересованность в финансировании } \\
\text { проекта. }\end{array}$ \\
\hline III. СТРУКТУРИРОВАНИЕ & $\begin{aligned} \checkmark & \text { ВЭБ.РФ обеспечивает единое } \\
& \text { информационное поле (Data Room); } \\
\checkmark & \text { совместное структурирование } \\
& \text { финансирования с учетом господдержки; } \\
\checkmark & \text { заключение договора синдицированного } \\
& \text { кредита. }\end{aligned}$ \\
\hline $\begin{array}{c}\text { IV. ФИНАНСИРОВАНИЕ } \\
\text { И МОНИТОРИНГ }\end{array}$ & $\begin{aligned} & \text { финансирование проекта в рамках } \\
& \text { синдиката (ВЭБ.РФ кредитный } \\
& \text { управляющий); } \\
\checkmark & \text { получение субсидии и государственной } \\
& \text { гарантии; } \\
\checkmark & \text { выпуск облигаций; } \\
\checkmark & \text { предоставление кредиторам доступа к } \\
& \text { информационным ресурсам с данными о } \\
& \text { реализации проекта. }\end{aligned}$ \\
\hline
\end{tabular}

Перечислим некоторые реализованные и реализовываемые проекты Фабрикой проектного финансирования ВЭБ.РФ с 2010 по 2020 гг. по следующим направлениям: [3].

- Инфраструктура:

$\checkmark$ новый пассажирский терминал аэропорта в Хабаровске - стоимость проекта 5 млрд. руб. из них объем участия ВЭБ 3,9 млрд. руб.;

$\checkmark$ объединенный транспортно-логистический комплекс в Калужской области - стоимость проекта 4,6 млрд. руб. из них объем участия ВЭБ 3,7 млрд. руб.

- Авиащия:

$\checkmark$ проект по разработке и организации производства самолета МС-21 стоимость проекта 291,5 млрд. руб. из них объем участия ВЭБ 7,1 млрд. руб.;

$\checkmark$ создание производства авиационных агрегатов НПО «Наука» стоимость проекта 4,6 млрд. руб. из них объем участия ВЭБ 3,7 млрд. руб.;

$\checkmark$ создание семейства самолетов Sukhoi Superjet 100 - стоимость проекта 150,8 млрд. руб. из них объем участия ВЭБ 73 млрд. руб.

- Высокие технологии:

$\checkmark$ производство серной кислоты марки "К" и улучшенного олеума "КуйбышевАзот" - стоимость проекта 6,3 млрд. руб. из них объем участия ВЭБ 3,8 млрд. руб.

- Информационно-коммуникационные технологии:

$\checkmark$ дата-центр в Санкт-Петербурге - стоимость проекта 3 млрд. руб. из них объем участия ВЭБ 2,2 млрд. руб.

- Космос: 
$\checkmark$ космический аппарат «Экспресс-АМ7»- стоимость проекта 11,7 млрд. руб. из них объем участия ВЭБ 7,7 млрд. руб.

- Микроэлектроника:

$\checkmark$ производство синтетического сапфира для оптоэлектроники стоимость проекта 5,2 млрд. руб. из них объем участия ВЭБ 3 млрд. руб.

- Электроэнергетика:

$\checkmark$ АЭС в Белоруссии - стоимость проекта 9 млрд. руб. из них объем участия ВЭБ 0,5 млрд. руб.;

$\checkmark$ реконструкция Нижнетуринской ГРЭС - стоимость проекта 19,9 млрд. руб. из них объем участия ВЭБ 15,5 млрд. руб.;

$\checkmark$ Богучанская ГЭС - стоимость проекта 72,5 млрд. руб. из них объем участия ВЭБ 28,1 млрд. руб.;

$\checkmark$ реконструкция Ижевской ТЭЦ-1 - стоимость проекта 10,3 млрд. руб. из них объем участия ВЭБ 8,3 млрд. руб..

Для характеристики удельного веса стоимости проектов по отдельным направлениям в общем объеме проектного финансирования обратимся к диаграмме (рис.2).

54,50\% Развитие инфраструктуры
21,80\% Повышение эффективности
природных ресурсов
9,80\% Национальные проекты
4,90\% Поддержка экспорта
3,10\% Прочие
1,70\% Развитие инноваций
0,50\% Повышение
энергоэффективности

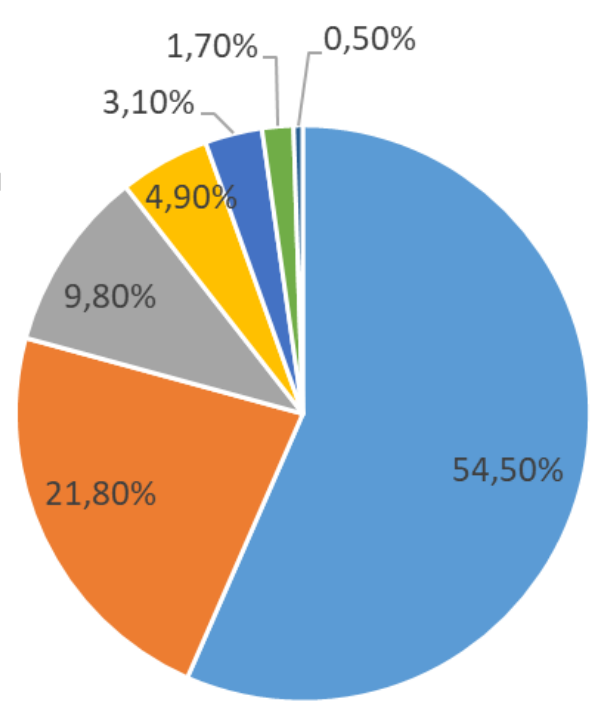

Рис. 2 - Распределение проектов по отдельным направлениям [7]

Все перечисленные проекты, реализуемые государственной корпорацией развития ВЭБ.РФ имеет следующими ключевые требованиями:

1. Общая стоимость проекта свыше 1 млрд. руб.

2. Минимальный совокупный размер участия ВЭБ.РФ - 500 млн. руб.

3. Срок окупаемости проекта более 1 года.

4. Срок финансирования - ВЭБ.РФ предоставляет преимущественно среднесрочное (от 1 года до 3 лет) и долгосрочное (более 3 лет) финансирование на возвратной основе. Участвует в капитале коммерческой 
организации - не более 10 лет (не более 20 лет - по направлению «развитие инфраструктуры и снятие инфраструктурных ограничений экономического роста»).

5. Соответствие направлениям инвестиций или отрасли проекта Стратегии и Меморандуму.

6. Безубыточность проекта.

Инициатор проекта и банк являются не окончательными звеньями при реализации проектов путем проектного финансирования, что в свою очередь повышает шансы реализации проекта и оптимизируют риски. К таким проектам могут относиться инновационные проекты, по которым можно спланировать объем продаж, выручку, затраты, т.е. конечный результат. Ответственность и риски распределяются между участниками проекта и регулируются набором контрактов и соглашений $[6,119]$.

Подводя итог можно сказать, что главным преимуществом проектного финансирования является возможность сконцентрировать значительные денежные ресурсы на решении конкретной хозяйственной задачи и локализовать риски проекта на проектной компании, создаваемой для выполнения конкретного проекта и использование именно проектной компании, является отличительной особенностью данного вида финансирования.

\section{Исследование выполнено при финансовой поддержке РФФИ в рамках научного проекта № 19-310-90024.}

\section{Список литературы}

1. Проектное финансирование и анализ: учеб. пособие для бакалавриата и магистратуры / М. А. Федотова, И. А. Никонова, Н. А. Лысова, - М.: Издательство Юрайт, 2017. - 144 с.

2. Журнал. Московский железнодорожник. Выпуск №38, 2013 г.

3. Федеральный закон $\mathrm{O}$ государственной корпорации развития «ВЭБ.РФ» №82ФЗ от 17.05.2007 г. [Электронный ресурс]. - Режим доступа: https://xn--90ab5f.xn--p1ai/files/?file=bab018429ae5e2dd361bc2c95e574bc2.pdf;

4. [Электронный pecypc] — Режим доступа: https://xn--90ab5f.xn-p1ai/files/?file=8ce22b13c6e1e914552a5424ced9d3d6.pdf.

5. [Электронный ресурс]. — Режим доступа: https://xn--90ab5f.xn-p1ai/biznesu/fabrika-proektnogo-finansirovaniya/.

6. Собина Н.В., Логинов М.П. / Механизм и система проектного финансирования. / Вопросы управления, 2017 № 02 (45) 119 с.

7. [Электронный ресурс]. — Режим доступа: https://xn--90ab5f.xn-p1ai/proyekty/.

8. Хаханаев У.С.-Э. Исследование факторов снижения рисков финансирования инвестпроектов // Финансы и кредит. - 2019. - Т. 25, № 9. C. 2167-2178. 